\title{
FLORA OF NEPAL NOTULAE II: PHLOMOIDES LONGIDENTATA PENDRY, A NEW SPECIES OF LABIATAE FROM NEPAL AND BHUTAN
}

\section{A. Pendry}

\begin{abstract}
The species Phlomoides longidentata Pendry is described from Nepal and Bhutan and a key to the species of Phlomoides in Nepal is presented.
\end{abstract}

Keywords. Nepal, new species, Phlomis, Phlomoides, Phlomoides longidentata.

Received 6 June 2018 Accepted 25 February 2020 Published 2 June 2021

\section{Introduction}

In the Enumeration of the Flowering Plants of Nepal (Press in Hara et al., 1982) and the Annotated Checklist of the Flowering Plants of Nepal (Press et al., 2000), the Nepalese species of the tribe Phlomideae Mathiesen are treated as Phlomis L. and Notochaete Benth. However, following their phylogenetic analysis of the Phlomideae, Salmaki et al. (2012) recognised a greatly reduced circumscription of Phlomis, with all the tribe's other species, including all the Himalayan and Chinese taxa, transferred to a much expanded Phlomoides Moench.

During the revision of the genus Phlomoides for the Flora of Nepal, a significant number of specimens were noted that did not correspond well with the Phlomoides species previously recorded from $\mathrm{Nepal}$ or its surrounding countries. They are recognised here as a new species, which is named as Phlomoides longidentata Pendry for its distinctive calyx teeth.

\section{Discussion}

During her revision of Phlomis (= Phlomoides) for the Flora of Bhutan, Clement (1999) identified several herbarium specimens as 'aff. Phlomis tibetica C.Marquand \& Airy Shaw' (= Phlomoides tibetica (C.Marquand \& Airy Shaw) Kamelin \& Makhm.) or 'cf. Phlomis tibetica', and noted that they were probably hybrids. However, these specimens, and others from Nepal, are sufficiently different from Phlomoides tibetica, and sufficiently widespread and numerous, that they are considered a distinct species, described here as $P$. longidentata on account of the prominent, spine-like calyx teeth (see Figures 1 and 2).

The lower teeth of the calyx of Phlomoides longidentata are spreading and 4-6 mm in length, and the upper teeth are erect and 1.5-4 mm long; in pressed material the lower teeth often appear to be sharply reflexed. In Phlomoides tibetica the calyx teeth are erect, equal and 1-1.5 mm long. Furthermore, Phlomoides tibetica has prominent dark-brown hairs on 


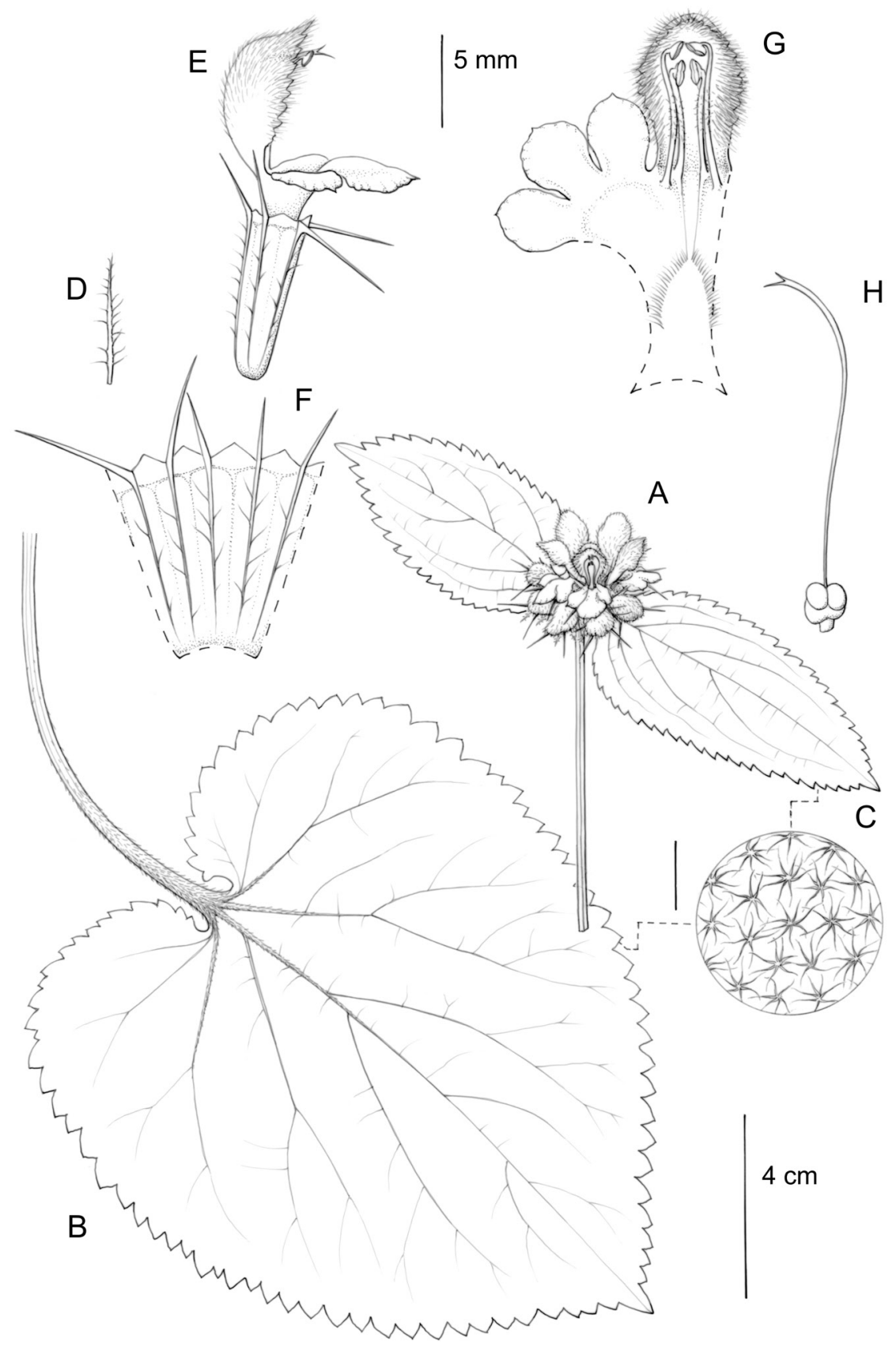

Figure 1. Phlomoides longidentata Pendry, sp. nov. A, Inflorescence and bracts; $\mathrm{B}$, basal leaf, upper surface; $C$, detail of stellate indumentum of lower leaf surface; $D$, bracteole; $E$, side view of flower; F, opened calyx, outer view; $G$, opened corolla; $H$, ovary and style. Scale bars: A and B, $4 \mathrm{~cm}$; , $0.05 \mathrm{~mm}$; D-H, $5 \mathrm{~mm}$. Drawn from DNEP3 BX36 by Claire Banks. 


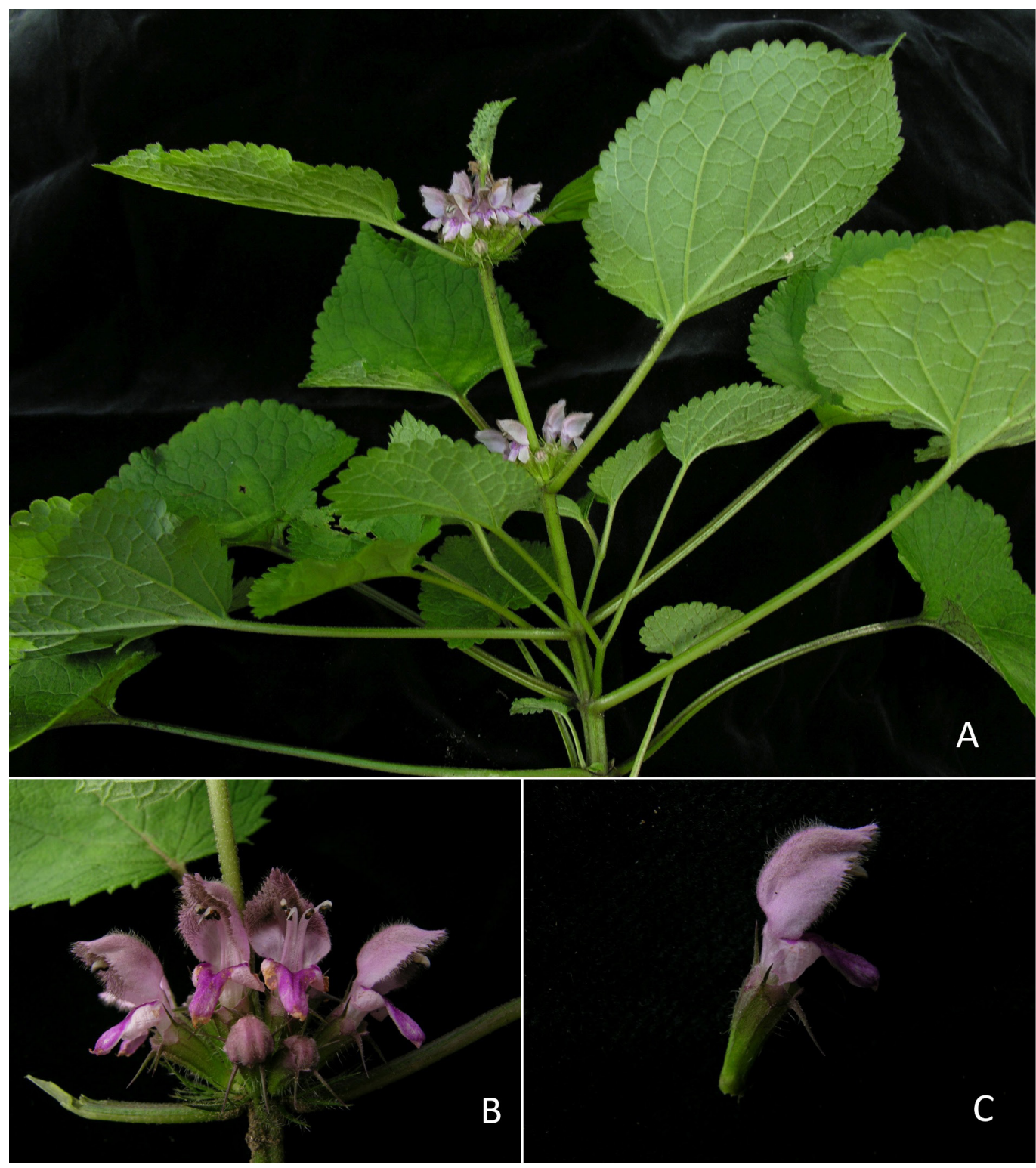

Figure 2. Phlomoides longidentata Pendry, sp. nov. (from DNEP3 BY205). A, Upper part of plant (DNEP3 BX36); B, close-up of inflorescence; $C$, side view of flower. All photographs by C. A. Pendry.

its calyces and bracteoles that are not seen in $P$. longidentata, and it never exceeds $50 \mathrm{~cm}$, whereas $P$. longidentata reaches $1 \mathrm{~m}$ in height. In its larger stature Phlomoides longidentata resembles $P$. macrophylla (Benth.) Kamelin \& Makhm. and $P$. breviflora (Benth.) Kamelin \& Makhm., but these species both have shorter, equal or subequal calyx teeth, and the latter 
has much shorter corollas (11-14 $\mathrm{mm}$ versus $14-20 \mathrm{~mm}$ ) and 5-veined, not 10-veined, calyces. The undersides of the leaves of both Phlomoides macrophylla and P. breviflora are sparsely villous or minutely stellate-hairy, rarely glabrous and not evenly stellate-hairy as in P. longidentata. Phlomoides spectabilis (Falc. ex Benth.) Kamelin \& Makhm. also has unequal calyx teeth and is evenly stellate-tomentose on the lower surface of its leaves, but this shorter, perennial species is easily distinguished from $P$. longidentata by the larger leaves and dense indumentum of stellate hairs all over its stems, petioles, bracteoles and calyces, which give it a silvery look throughout. Phlomoides bracteosa (Royle ex Benth.) Kamelin \& Makhm. sometimes has stellate hairs on the undersides of its leaves, but it is clearly separable from all the other Nepalese species of Phlomoides by the conspicuous row of $2 \mathrm{~mm}$-wide bracteoles that surrounds its verticillasters. The differences between these species are summarised in the Table.

\section{Species description}

Phlomoides longidentata Pendry, sp. nov.

Phlomoides longidentata differs from P. bracteosa (Royle ex Benth.) Kamelin \& Makhm., P. breviflora (Benth.) Kamelin \& Makhm., P. macrophylla (Benth.) Kamelin \& Makhm. and $P$. tibetica (C.Marquand \& Airy Shaw) Kamelin \& Makhm. in its longer, unequal calyx teeth, and from $P$. spectabilis (Falc. ex Benth.) Kamelin \& Makhm. in its greater stature, its annual growth form, and its villous to sparsely stellate hairy calyx and bracteoles. - Type: Nepal, Solukhumbu District, Namche Bazar, above bridge over Dudh Kosi. $27^{\circ} 47^{\prime} 31^{\prime \prime} \mathrm{N}$ 8642'57"E, 3060 m, 12 ix 2006 (fl), DNEP3 BX36 (holotype E; isotypes KATH, TI, TUCH).

Table. Summary of differences between Phlomoides longidentata Pendry and similar species of Phlomoides in Nepal and Bhutan

\begin{tabular}{|c|c|c|c|c|c|c|}
\hline Species & $\begin{array}{l}\text { Annual or } \\
\text { perennial }\end{array}$ & $\begin{array}{l}\text { Maximum } \\
\text { height } \\
(\mathrm{cm})\end{array}$ & $\begin{array}{l}\text { Leaf } \\
\text { dimensions } \\
(\mathrm{cm})\end{array}$ & $\begin{array}{l}\text { Indumentum on underside of } \\
\text { leaves }\end{array}$ & $\begin{array}{l}\text { Corolla } \\
\text { length } \\
(\mathrm{mm})\end{array}$ & $\begin{array}{l}\text { Calyx teeth } \\
\text { length } \\
(\mathrm{mm})\end{array}$ \\
\hline P. longidentata & Annual & 100 & $\begin{array}{l}5-16 \times \\
4-13\end{array}$ & Densely evenly stellate hairy & $14-20$ & $1.5-4,4-6$ \\
\hline P. bracteosa & Annual & $70(150)$ & $\begin{array}{l}5-18 \times \\
3-13\end{array}$ & Villous to sparsely stellate hairy & $17-19$ & $1-3$ \\
\hline P. breviflora & Perennial & 150 & $\begin{array}{l}12-22 \times \\
8-17\end{array}$ & $\begin{array}{l}\text { Sparsely stellate or villous } \\
\text { pubescent below }\end{array}$ & $11-14$ & $1.5-3$ \\
\hline P. macrophylla & Perennial & 200 & $\begin{array}{l}10-18 \times \\
6-12\end{array}$ & $\begin{array}{l}\text { Sparsely villous or minutely } \\
\text { stellate hairy to glabrous, } \\
\text { denser on the veins }\end{array}$ & $17-22$ & $1-3$ \\
\hline P. spectabilis & Perennial & 40 & $\begin{array}{l}12-20 \times \\
8-13\end{array}$ & Densely evenly stellate hairy & $18-20$ & $2-3,4-5$ \\
\hline P. tibetica & Annual & 50 & $\begin{array}{l}4-10 \times \\
2.5-8\end{array}$ & Villous to stellate hairy & $18-20$ & $1-1.5$ \\
\hline
\end{tabular}


Annual herb to $1 \mathrm{~m}$. Indumentum of simple and stellate hairs. Stems more or less densely villous and stellate hairy, glabrescent. Petioles $2-20 \mathrm{~cm}$, up to $3 \mathrm{~mm}$ thick, with the petioles usually much longer on lower leaves. Leaves ovate, $5-16 \times 3-13 \mathrm{~cm}$, base cordate to truncate, apex acute, margin serrate, sparsely villous or stellate hairy above, densely evenly stellate hairy below. Inflorescences axillary, few- to many-flowered. Bracts similar to stem leaves in shape and indumentum but smaller, 1.5-10 × 1-6 cm. Bracteoles acicular to narrowly winged, 7-8 mm, ciliate. Calyx tube obconical, 10-veined, 9-11 mm, villous or sparsely stellate hairy, teeth spinose, unequal, upper teeth 1.5-4 $\mathrm{mm}$, erect or spreading, lower teeth usually larger, reflexed, 4-6 mm. Corolla pale pink to purple, 14-20 mm, tube 8-13 $\mathrm{mm}$ with an oblique annulus near the base, upper lip 6-8 $\mathrm{mm}$, hooded, densely brownish villous inside with shorter, sparser, whitish hairs outside, lower lip 6-7 mm, pale villous on lower surface, middle lobe darker than the rest of the corolla, 4-5 mm, obtuse, lateral lobes 2-4 mm, obtuse. Stamens unequal, free parts 5-9 $\mathrm{mm}$, glabrous. Style more or less curved, 13-20 mm, unequally 2-lobed. Nutlets: mature nutlets not seen, immature nutlets blackish brown, oblong, flattened, 3-4 mm, with a small, circular attachment scar at the base.

Altitudinal range. 2000-3800 m.

Ecology. Grassy slopes and open areas in Pinus wallichiiana, Tsuga-Rhododendron and Quercus forest.

Distribution. Nepal, Bhutan.

Additional specimens examined. BHutAN. Thimpu: Dotena, 8000 ft, 16 vii 1914, Cooper 1560 (E), 3300 m, 20 viii 1989, Rose King 1109 (E); Dochong La, 3080 m, 1 ix 1984, Sinclair \& Long 4751 (E); Paro, 7 ix 1983, Sargent 254 (E).

NEPAL. Dolakha: Rolwaling, 12,300 ft, 1 viii 1974, Sacherer s.n. (E). Kalikot: Panipokhari to Chaukebada, 2020-2440 m, 4 viii 1991, Suzuki et al. 9160203 (TI). Mustang: Ghasa, 10,000 ft, 4 iv 1954, Stainton, Sykes \& Williams 1522 (BM, E). Rukum: Ghasdung Khola, 10,000 ft, 6 vi 1954, Stainton, Sykes \& Williams 3396 (BM, E); Ghasdung Khola, 2935 m, 26 viii 2014, BRD A122 (E, KATH). Solukhumbu: Namche Bazar, above bridge over Dudh Kosi, 3060 m, 12 ix 2006, DNEP3 BX35 (E, KATH, TI, TUCH), DNEP3 BY205 (E, KATH, TI, TUCH); Pike Khop to Fera, 2435 m, 25 vii 1995, Miyamoto et al. 9596140 (E); Sete to Tak Tor, 2550-3400 m, 19 viii 1985, Ohba et al. 8580979 (E); Kurki to Khari Khola, 3180 m, 29 viii 1997, Wakabayashi et al. 9720324 (TI). District unknown: 1930, Dhwoj 356 (E).

\section{Key to the species of Phlomoides in Nepal}

1a. Rosette-forming herbs with leaves appressed to the ground. Flowering stems occasionally to $20 \mathrm{~cm}$. Petioles flattened, up to $1.5 \mathrm{~cm}$ broad P. rotata

1b. Erect herbs with evenly spaced leaves. Flowering stems at least $20 \mathrm{~cm}$ tall. Petioles terete, up to $0.5 \mathrm{~cm}$ thick 
2a. Calyx teeth strongly hooked apically P. hamosa

2b. Calyx teeth straight, unhooked 3

3a. Widest bracteoles c. $2 \mathrm{~mm}$ wide P. bracteosa

3b. Bracteoles less than $1.5 \mathrm{~mm}$ wide 4

4a. Calyx teeth unequal, spreading, 2-6 $\mathrm{mm}$, lower teeth longer 5

4b. Calyx teeth equal to subequal, erect, $1-3 \mathrm{~mm}$ 6

5a. Perennial herbs to $40 \mathrm{~cm}$, with stout rootstock. Calyx and bracteoles densely stellate hairy P. spectabilis

5b. Annual herbs to $100 \mathrm{~cm}$. Calyx and bracteoles villous, sometimes with sparse stellate hairs P. longidentata

6a. Annual herb to $50 \mathrm{~cm}$. Calyx and bracteoles villous with brown hairs. Leaves bullate P. tibetica

6b. Perennial herb to $1(-2) \mathrm{m}$. Calyx and bracteoles with pale hairs. Leaves flat 7

7a. Calyx tube 5-veined, 7-8 $\mathrm{mm}$. Corolla 11-14 $\mathrm{mm}$ P. breviflora

7b. Calyx tube 10-veined, 10-11 mm. Corolla 17-22 mm P. macrophylla

\section{Acknowledgements}

I would like to thank Claire Banks for her excellent illustration.

The curators of BM and $E$ are thanked for access to their specimens.

The Royal Botanic Garden Edinburgh is supported by the Scottish Government's Rural and Environment Science and Analytical Services Division. RBGE is also grateful for the support of players of People's Postcode Lottery towards our scientific research.

\section{References}

Clement RA. 1999. Labiatae. In: Long DG, editor. Flora of Bhutan, vol. 2, part 2. Edinburgh: Royal Botanic Garden Edinburgh. pp. 938-1002.

Hara H, Stearn WT, Williams WT, Chater AO. 1982. An Enumeration of the Flowering Plants of Nepal, volume 3. London: British Museum (Natural History).

Press JR, Shrestha KKS, Sutton DA. 2000. Annotated Checklist of the Flowering Plants of Nepal. London: British Museum (Natural History).

Salmaki Y, Zarre S, Ryding O, Lindqvist C, Scheunert A, Brauchler C, Heubl G. 2012. Phylogeny of the tribe Phlomideae (Lamioideae: Lamiaceae) with special focus on Eremostachys and Phlomoides: new insights from nuclear and chloroplast sequences. Taxon. 61(1):161-179. 